\title{
Bacterial diversity in adjacent kelp-dominated ecosystems
}

\author{
C. L. Davis ${ }^{1}$, K. Koop ${ }^{2 *}$, D. G. Muir ${ }^{1}$ and F. T. Robb ${ }^{1 *}$ \\ ${ }^{1}$ Microbiology Department, University of Cape Town, Rondebosch 7700, South Africa \\ ${ }^{2}$ Zoology Department, University of Cape Town, Rondebosch 7700, South Africa
}

\begin{abstract}
Bacteria in kelp-related ecosystems on the west coast of South Africa were isolated using random sampling techniques. The percentage of bacteria forming colonies on solid media was determined. The population composition in 4 adjacent habitats was determined by morphological and physiological criteria. These data were analysed by cluster analysis using the Bray-Curtis measure of similarity. Isolates from inshore waters were able to ferment a wide range of kelp-derived products, whereas offshore isolates had a more restricted spectrum of fermentable substrates. The similarity analysis indicates that bacteria isolated from the 4 adjacent habitats are essentially different. It is suggested that bacterial assemblages in adjacent habitats segregate into discrete populations in response to physical, chemical and biological factors.
\end{abstract}

\section{INTRODUCTION}

Recent work on the ecology of the west coast of South Africa has concentrated on the dispersion of kelp-derived material into the associated food webs (Linley et al., 1981; Lucas et al., 1981; Newell et al., 1982). Heterotrophic utilisation of kelp-derived mucilage and fragmented particles as well as beached kelp debris has been shown to depend to a large extent on bacterial action (Linley et al., 1981; Stuart et al., 1981, Koop et al., 1982a). In a detailed analysis of the soluble organic components of the 2 main kelp species in South African waters - Ecklonia maxima (Osbeck) and Laminaria pallida (Grev.) J. Agr. - Newell et al. (1980) have indicated that $\mathrm{D}$-mannitol dominates the soluble carbohydrates in kelp. It is the primary photosynthate and represents $77 \%$ by weight of the total free sugars and polyols. Polysaccharide components are principally alginates and laminarins which amount to about 5 and $7 \%$ of the dry weight of kelp mucilage, respectively. These carbohydrates represent a large proportion of the energy available for transfer to successive trophic levels, and the heterotrophic organisms associ-

\footnotetext{
- Present address: School of Biological Sciences, University of Sydney, Sydney, NSW 2006, Australia

- Addressee for correspondence
}

ated with kelp utilise these components efficiently (Stuart et al., 1981).

Linley and Newell (1981), Newell and Lucas (1981) and Stuart et al. (1981) have established that conversion systems of the soluble and refractory organic components of kelp can be driven by natural microheterotrophic populations in flask containment. The conversion of kelp material into bacterial biomass in the field has been studied by Koop et al. (1982b, c). They have shown that $\mathrm{D}$-mannitol is utilised within $48 \mathrm{~h}$ by bacterial populations, and that the total conversion efficiency of kelp carbon into bacterial carbon can vary between $12 \%$ (winter) and $29.4 \%$ (summer). A succession of microbes has been reported in seawater incubated with kelp mucilage, in which bacteria were initially dominant, followed by flagellates and ciliates which consumed the bacteria (Linley et al., 1981; Stuart et al., 1981). Recently published evidence suggests that differences exist between the bacterial populations of nearshore, kelp-dominated, and offshore, phytoplankton-dominated water. This has led to the hypothesis that bacteria in adjacent habitats separate into discrete communities which may be identified on the basis of their hydrolytic properties (Koop et al., 1982a).

Although a good deal is now known about the ecological role of the bacteria in the kelp beds off the 
West Coast of the Cape Peninsula, there is little published information on the distribution and the characteristics of these organisms. In this paper we examine the distribution and properties of naturally occurring bacteria in random samples, and compare the samples using numerical analysis.

\section{MATERIALS AND METHODS}

\section{Sampling site}

All samples were collected at Kommetjie, on the west coast of the Cape Peninsula, South Africa. Samples were assembled during summer.

\section{Determination of bacterial cell counts}

Total cell count was determined using the method of Hobbie et al. (1977). Duplicate $10 \mathrm{ml}$ samples were filtered directly onto $0.22 \mu \mathrm{m}$ Nuclepore filters (Nuclepore Corporation, Pleasanton, California) and simultaneously $0.1 \mathrm{ml}$ samples were plated onto seawater agar. Duplicate samples for determination of ultramicrobacteria (MacDonell and Hood, 1982) were filtered through $0.45 \mu \mathrm{m}$ onto $0.22 \mu \mathrm{m}$ filters which were then analysed as described above.

\section{Culture methods, media and isolation of bacterial strains}

Culture media were based on natural seawater collected from the study site. Liquid growth medium (seawater broth) contained 3 parts of filtered (Whatmans No 1) seawater with 1 part of glass distilled water and $0.5 \% \mathrm{w} / \mathrm{v}$ peptone (Oxoid), $0.1 \% \mathrm{w} / \mathrm{v}$ yeast extract (Difco) and $0.01 \% \mathrm{w} / \mathrm{v}$ ferric phosphate (Mazure and Field, 1980). All isolates grew rapidly in this medium at either 25 or $30^{\circ} \mathrm{C}$ with shaking. Growth of the isolates at $10^{\circ} \mathrm{C}$ is slower than at $25^{\circ} \mathrm{C}$, but does not alter the responses of the organisms in the physiological tests. Solid medium for plating or storage was prepared by the addition of $1.5 \%$ agar to the medium (seawater agar). The media were sterilised by autoclaving.

\section{Sampling methods}

Water samples were collected in sterile glass bottles from 4 adjacent habitats: (1) A nearshore water-column sample was taken at the surface within the Kommetjie kelp bed. (2) An offshore water-column sample was taken at the surface $12 \mathrm{~km}$ west of Kommetjie. (3) A sample of liquified, degraded kelp fluids was taken underneath beached kelp. (4) A sample of interstitial water was taken from sand on an adjacent exposed sandy beach.

A sample from each habitat was spread onto seawater agar plates and incubated for $48 \mathrm{~h}$ at room temperature, after a dilution series had been prepared to obtain standard Petri dishes containing about 100 colonies each. Working from the perimeter of each plate towards the centre, the first 40 colonies encountered were isolated. These were restreaked to purity.

Each of the 160 isolates was tested for the following properties: (1) gram reaction; (2) motility; (3) mannitol fermentation; (4) glucose fermentation; (5) agarolytic activity using Gran's test (Hodgson and Chater, 1981).

\section{Assay of hydrolytic activities}

Fermentation of mannitol and glucose was measured using an indicator medium of $1 \%$ peptone (Oxoid), $1 \%$ carbon source and $10^{-4} \%$ phenol red in natural $0.2 \mu \mathrm{m}$ filtered seawater. This medium gives results identical to those recorded using the more complex Leifson's medium modified by addition of $1 \%(\mathrm{w} / \mathrm{v})$ carbon source. All fermentation tests were carried out under aerobic conditions and repeated in an anaerobic jar perfused with high purity nitrogen.

\section{Data analysis}

Within each strain collection, a list of properties of the 40 strains was compiled. Strains exhibiting identical responses were arbitrarily assigned into taxa. The number of taxa in each collection and the total number of taxa in the 4 collections were calculated. In this way, each taxon might consist of several strains but, with regard to the properties tested, these strains could be justifiably grouped together for further analysis. The data from the 4 collections were subjected to cluster analysis (Clifford and Stephenson, 1975). The strategy outlined by Field et al. (1982) was adopted using the Bray-Curtis measure of dissimilarity on untransformed data. A factor in favour of selecting the Bray-Curtis measure was that it does not take into account joint absences (Field et al., 1982).

The data matrix consisted of 4 individuals (the habitats): Nearshore, offshore, beached kelp, and interstitial water, by 15 attributes (the taxa). Each taxon differed from the others by at least one physiological property. The analytical procedure used was exactly as described in detail by Field et al. (1982). 


\section{RESULTS}

\section{Bacterial cell counts}

Table 1 summarises the comparison between total bacterial cell numbers and the platable fraction of bacteria. Offshore waters contain only a small fraction

Table 1. Total bacterial counts compared with numbers of colony forming bacteria in samples representing the habitats examined in this study

\begin{tabular}{|c|c|c|c|}
\hline Samples & $\begin{array}{c}\text { Total cell } \\
\text { count } \\
\text { (cells } \mathrm{ml}^{-1} \text { ) }\end{array}$ & $\begin{array}{c}\text { Colony } \\
\text { forming } \\
\text { bacteria } \mathrm{ml}^{-1}\end{array}$ & $\begin{array}{c}\% \text { of total } \\
\text { plateable } \\
\text { bacteria }\end{array}$ \\
\hline \multirow{2}{*}{ Nearshore } & ${ }^{1} 1.4 \times 10^{5}$ & $3.6 \times 10^{3}$ & 3.8 \\
\hline & $23.9 \times 10^{4}$ & 0 & - \\
\hline \multirow[t]{2}{*}{ Offshore } & ${ }^{1} 3.5 \times 10^{5}$ & $8.0 \times 10^{3}$ & 2.2 \\
\hline & ${ }^{2} 1.7 \times 10^{5}$ & 0 & - \\
\hline Interstitial & ${ }^{1} 7.5 \times 10^{7}$ & $1.3 \times 10^{7}$ & 17.0 \\
\hline Beached kelp & ${ }^{1} 2.3 \times 10^{9}$ & $3.2 \times 10^{8}$ & 13.0 \\
\hline
\end{tabular}

of plateable bacteria. Roughly half of the water column bacteria were sufficiently small to pass through a $0.45 \mu \mathrm{m}$ filter, and these ultramicrobacteria were totally recalcitrant to plating. The onshore samples contained a far higher proportion of colony-forming bacteria than the offshore samples.

\section{Characterisation of randomly sampled collections}

The characteristics of collections of 40 randomly sampled strains from 4 adjacent marine habitats are summarised in Tables 2 and 3.

Table 2 presents the Gram reactions and motility of isolates from the 4 collections as well as several catabolic properties. The bacteria from the water-column samples were Gram negative without exception, whereas a small number of Gram positive strains occurred in the onshore samples. Motile strains occurred frequently in the nearshore, offshore and interstitial samples, and rarely in the sample from beached kelp. The bacterial isolates designated as fermenters in Table 2 were facultative anaerobic strains which were tested in parallel on mannitol and glucose. The beached kelp sample contained a significantly higher number of fermenters than the other samples. The interstitial sample contained a minor component of fermenters. Agarolysis was not found in any of the beached kelp strains and was most common in the nearshore collection.
Table 2. Summary of properties of bacterial populations from the nearshore water of a kelp bed, from water more than 4.5 $\mathrm{km}$ offshore, from the interstitial water of an adjacent exposed sandy beach, and from degrading, beached kelp plants. Data represent numbers of bacterial strains exhibiting the properties tested; percentage of the total number of strains within each population (40) is also shown

\begin{tabular}{|c|c|c|c|c|}
\hline \multirow{2}{*}{ Properties } & \multicolumn{4}{|c|}{ Population } \\
\hline & $\begin{array}{l}\text { Near- } \\
\text { shore }\end{array}$ & $\begin{array}{l}\text { Off- } \\
\text { shore }\end{array}$ & $\begin{array}{l}\text { Inter- } \\
\text { stitial }\end{array}$ & $\begin{array}{c}\text { Beached } \\
\text { kelp }\end{array}$ \\
\hline \multirow[t]{2}{*}{ Gram negative } & 40 & 40 & 37 & 36 \\
\hline & $100 \%$ & $100 \%$ & $92.5 \%$ & $90 \%$ \\
\hline \multirow[t]{2}{*}{ Motile } & 39 & 35 & 36 & 2 \\
\hline & $97.5 \%$ & $87.5 \%$ & $90 \%$ & $5 \%$ \\
\hline \multirow[t]{2}{*}{ Fermenters } & 25 & 25 & 2 & 37 \\
\hline & $62.5 \%$ & $62.5 \%$ & $5 \%$ & $92.5 \%$ \\
\hline \multirow[t]{2}{*}{ Agar digestion } & 8 & 3 & 2 & 0 \\
\hline & $20 \%$ & $7.5 \%$ & $5.0 \%$ & $0 \%$ \\
\hline
\end{tabular}

Table 3. Properties of facultative anaerobes from the nearshore water of a kelp bed, from water more than $4.5 \mathrm{~km}$ offshore, from the interstitial water of an adjacent sandy beach, and from degrading, beached kelp plants. Data represent the number of bacterial strains exhibiting the properties tested, expressed as a percentage of the facultative anaerobes in each sample

\begin{tabular}{|c|c|c|c|c|}
\hline \multirow[t]{2}{*}{ Fermentation } & \multicolumn{4}{|c|}{ Population } \\
\hline & $\begin{array}{l}\text { Near- } \\
\text { shore }\end{array}$ & $\begin{array}{l}\text { Off- } \\
\text { shore }\end{array}$ & $\begin{array}{l}\text { Inter- } \\
\text { stitial }\end{array}$ & $\begin{array}{c}\text { Beached } \\
\text { kelp }\end{array}$ \\
\hline \multirow[t]{2}{*}{ Mannitol } & 25 & 19 & 1 & 34 \\
\hline & $100 \%$ & $76 \%$ & $50 \%$ & $92 \%$ \\
\hline \multirow[t]{2}{*}{ Glucose } & 19 & 23 & 2 & 3 \\
\hline & $76 \%$ & $92 \%$ & $100 \%$ & $8 \%$ \\
\hline Mannitol only & 6 & 2 & 0 & 34 \\
\hline Glucose only & 0 & 6 & 1 & 3 \\
\hline Both substrates & 19 & 17 & 1 & 0 \\
\hline
\end{tabular}

Table 3 presents the fermentation spectra of the facultative anaerobes. The 2 fermenters in the interstitial sample both fermented glucose and not mannitol. The water column samples both contained a high proportion of fermenters with mannitol and glucose uptake systems, whereas the beached kelp sample contained the highest number of fermenters, most of which fermented mannitol and not glucose.

The specialisation of the populations is reflected in the cluster analysis. Both classification and ordination diagrams are shown (Fig. 1a and b) since only the latter reflect relationships between individual samples (Field et al. 1982). The 2 open-water populations from kelp-bed water and from the offshore region showed most similarity $(56 \%)$. The other 2 collections were distinctly dissimilar from these open-water communities as well as from each other. The interstitial collection appeared to be about equally dissimilar 

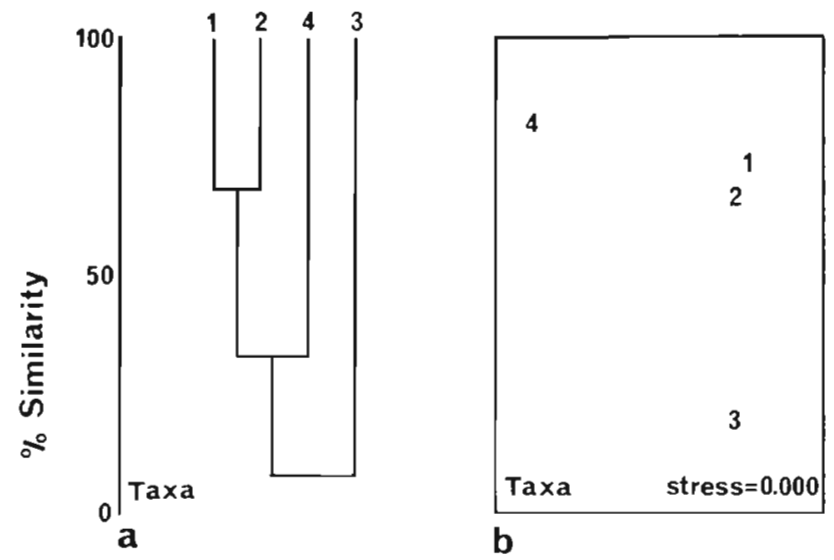

Fig. 1. Classification and ordination diagrams of 4 bacterial populations from adjacent habitats. Classification dendrograms were derived using untransformed data, comparing samples using the Bray-Curtis measure and employing group average sorting. Ordination employed multidimensional sca]ing. 1 = nearshore, 2 = offshore, $3=$ beached $\mathrm{kelp}, 4=$ interstitial water

from both the nearshore and the offshore communities, showing a separation at the $30 \%$ level. The bacterial collection from beached kelp appeared extremely isolated on the ordination diagram (3\% on the classification diagram) indicating as very high level of dissimilarity from all other poulations.

\section{DISCUSSION}

A relatively small proportion of the total water-column bacterial population was capable of colony formation. Current work has shown that free-living marine bacteria frequently occur as small coccoid forms, which are extremely fastidious. These strains can be rendered plateable by raising them through a series of very dilute media in which the nutrient concentration is gradually raised. Upon revival, these ultramicrobacteria have been classified and fall into conventional genera, principally Vibrio (MacDonell and Hood, 1982). These ultramicrobacteria probably represent inactive forms. Our results indicate that ultramicrobacteria are present in the offshore and inshore watercolumn samples. Shoreline samples contain a higher proportion of colony-forming bacteria which indicates that the ratios of active to inactive bacteria in the 4 samples are fundamentally different. It is felt that the plating technique used represents a proportion of the active bacterial populations, since the inactive, small forms are not capable of colony formation.

The similarity analysis (Fig. 1) suggests that the active bacterial assemblages in 4 adjacent marine habitats are essentially different. The bacteria collected from beached kelp are most dissimilar, com- pared with other groups. This group consists of a mixture of Gram-negative and Gram-positive strains, in which the Gram-negative organisms predominate. The assemblage is further distinguished by a high percentage of facultative anaerobes, most of which only ferment mannitol. Most strains are non-motile, in contrast to strains from all other habitats. This combination of characteristics reflects the environmental conditions. Gram-positive strains are limited to situations of high ambient nutrient concentration, since they release extracellular enzymes which would be wasted in systems where they are rapidly diluted, such as the water column (Sieburth, 1979). Rotting kelp clumps present a highly anaerobic, nutrient-rich environment, with abundant carbon (of which D-mannitol is the dominant polysaccharide) and nitrogen, and hence favour the selection of facultative anaerobes which ferment mannitol and not glucose.

The interstitial assemblage is distinguished from the other assemblages by its low percentage of facultative anaerobes, but shares the characteristic of a few Grampositive strains with the kelp sample. Interstitial bacteria adjacent to kelp clumps are subjected to high nitrogen and low carbon availability (Koop et al., 1982c). Water movement through the upper $30 \mathrm{~cm}$ of sand is rapid and anoxia is rare. It is suggested that anaerobiosis, which is a metabolically inefficient process, would thus be unnecessary and wasteful of low carbon sources. The interstitial bacteria share with the water column bacteria the characteristic of a high degree of motility which enables the maintenance of position in favourable microclimates. Of those fermenters which did occur, both fermented mannitol and glucose. In addition a small percentage were agarolytic as in the water column groups. This suggests that nutrients are derived both from decay processes higher on the shore and from input from the sea itself.

Nearshore and offshore groups, while differing markedly from onshore groups, are very similar to one another. All strains are Gram-negative and most are highly motile. A fairly high percentage of facultative anaerobes occur in both, and most of these ferment both mannitol and glucose, although subtle differences can be noted in their utilisation of the substrates. A higher percentage of strains in the inshore region ferment mannitol only, while the situation is reversed in favour of glucose in the offshore region. The principal difference between the groups is the far higher percentage of agarolytic strains in the inshore region. While the occurrence of agar in these waters is not documented, results suggest that agar or agar-like polysaccharides may be a characteristic carbon source for the nearshore region.

This study has shown that even in a dynamic upwelling system characterised by rapid movement of large 
water masses, bacteria in adjacent habitats segregate into discrete communities which are distinct in their properties. Bacteria thus appear to use their high degree of genetic flexibility to adapt effectively to both the physical conditions and substrates available to them in the particular habitats where they occur.

Acknowledgements. This work was supported by the Benguela Ecology Programme of the S.A. National Committee for Oceanographic Research. We thank William Petrie for excellent technical assistance, and Penny Brown and Larry Hutchings of the Sea Fisheries Institute for providing offshore water samples.

\section{LITERATURE CITED}

Clifford, H. T., Stephenson, W. (1975). An introduction to numerical classification. Academic Press, New York

Field, J. G., Clarke: K. R., Warwick, R. M. (1982). A practical strategy for analysing multispecies distribution patterns. Mar. Ecol. Prog. Ser. 8: 37-52

Hobbie, J. E., Daley, R. T., Jasper, S. (1977). Use of Nuclepore filters for counting bacteria by fluorescence microscopy. Appl. environ. Microbiol. 33: 1225-1228

Hodgson, D. A., Chater, K. F. (1981). A chromosomal locus controlling extracellular agarase production by Streptomyces coelicolor A3 (2), and its inactivation by chromosomal integration of plasmid SCPI. J. gen. Microbiol. 124: 339-348

Koop, K., Carter, R. A., Newell, R. C. (1982a). Mannitolfermenting bacteria as evidence for export from kelp beds. Limnol. Oceangr. 27: 950-954

Koop, K., Newell, R. C., Lucas, M. I. (1982b). Bjodegradation and carbon flow based on kelp (Ecklonia maxima) debris in a sandy beach microcosm. Mar. Ecol. Prog. Ser. 7 : $315-326$
Koop, K., Newell, R. C., Lucas, M. I. (1982c). Microbial regeneration of the nutrients from the decomposition of macrophyte debris on the shore. Mar. Ecol. Prog. Ser. 9: 91-96

Linley, E. A. S., Newell, R. C. (1981). Microheterotrophic communities associated with the degradation of kelp debris. Kieler Meeresforsch. 5 (Sonderh.): 345-355

Linley, E. A. S., Newell, R. C., Bosma, S. (1981). Heterotrophic utilisation of mucilage released during fragmentation of kelp (Ecklonia maxima and Laminaria pallida). 1. Development of microbial communities associated with the degradation of kelp mucilage. Mar, Ecol. Prog. Ser. 4: $31-41$

Lucas, M. I., Newell, R. C., Velimirov, B. (1981). Heterotrophic utilisation of mucilage released during fragmentation of kelp (Ecklonia maxima and Laminaria pallida). 2. Differential utilisation of dissolved organic components from kelp mucilage. Mar. Ecol. Prog. Ser. 4: 43-55

MacDonell, M. T., Hood, M. A. (1982). Isolation and characterisation of ultramicrobacteria from a Gulf Coast estuary Appl. environ. Microbiol. 43: 566-571

Mazure, H. G. F., Field, J. G. (1980). Density and ecological importance of bacteria on kelp fronds in an upwelling region. J. exp. mar. Biol. Ecol. 43: 173-182

Newell, R. C., Lucas, M. I. (1981). The quantitative significance of dissolved and particulate organic matter released during fragmentation of kelp in coastal waters. Kieler Meeresforsch. 5 (Sonderh.): 356-369

Newell, R. C., Field, J. G., Griffiths, C. L. (1982). Energy balance and the significance of microorganisms in a kelp bed community. Mar. Ecol. Prog. Ser. 8: 103-113

Newell, R. C., Lucas, M. I., Velimirov, B., Seiderer, L. J. (1980). The quantitative significance of dissolved organic losses following fragmentation of kelp (Ecklonia maxima and Laminaria pallida). Mar. Ecol. Prog. Ser. 2: 45-59

Sieburth, J. M. (1979). Sea microbes. Oxford University Press, New York

Stuart, V., Lucas, M. I., Newell, R. C. (1981). Heterotrophic utilisation of particulate matter from the kelp Laminaria pallida. Mar. Ecol. Prog. Ser, 4: 337-348

This paper was presented by Professor R. C. Newell; it was accepted for printing on June 8, 1983 